
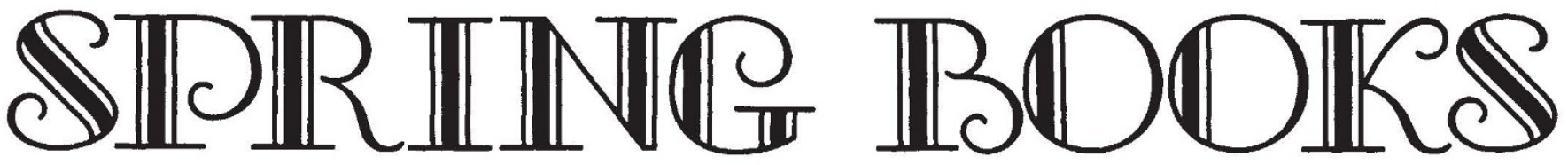

R. A. FISHER was one of the really great scientists of this century, a man of immense ability, with an independent mind of great penetration combined with wide interests and striking erudition. $\mathrm{He}$ is, of course, best known for his contributions to statistics and genetics, but he was interested in any variable phenomenon and indeed made a basic statistical contribution to the study of palaeomagnetism, whose implications for the theory of continental drift he both recognised and expounded. All these he combined with a capacity for eccentric behaviour which, though sometimes exasperating or embarrassing to his friends, is now chiefly remembered for its contribution to the seemingly inexhaustable fund of "Fisheriana"-some of it no doubt apochryphal but most of it firmly based on fact. It has indeed been said that in later years, biometrical meetings not uncommonly developed into gatherings engaged in telling endless stories about the master.

I had the privilege (and it was a privilege, even if at times a little wearing) of working closely with Fisher. in the Galton Laboratory, for several years in the mid-1930s. They were unforgettable years, and not just because they saw the publication of that great book. The Design of Experiments (which Fisher gave as a lecture course while he was writing it), the introduction of such new statistical techniques as discriminant functions, the analysis

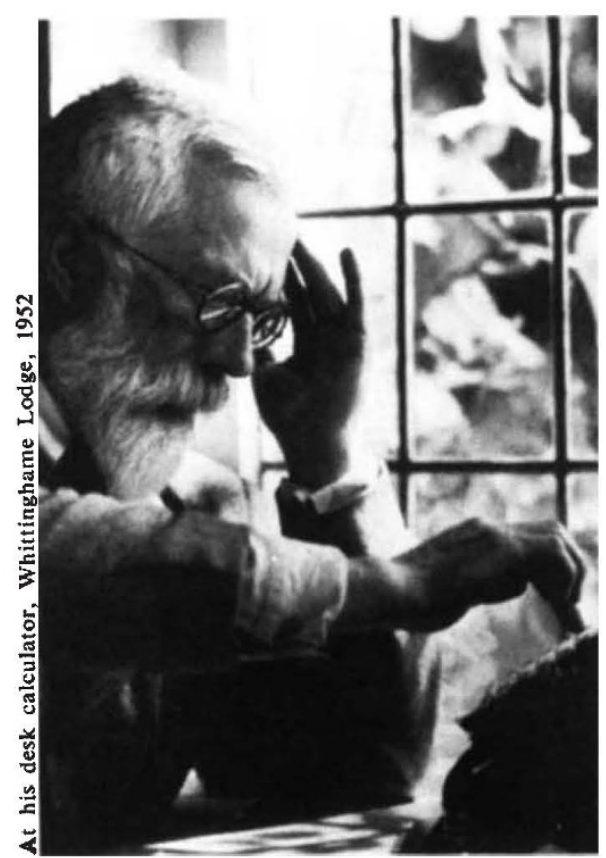

of Nabours' data from wild populations of grouse locusts which revealed selective differentials attaining the hitherto unheard of level of $10 \%$, or even the birth of the serological unit which was to unravel the complexities of the $R h$ gene and do so much for the study of human blood groups. They were unforgettable too for the way in which he gave unstintingly of his time in

\section{Life with Fisher}

\section{Kenneth Mather}

R. A. Fisher: The Life of a Scientist. By J. Fisher Box. Pp.512. (Wiley: New York and Chichester, UK, 1978.) £16.

explaining to a hitherto statistically uneducated young biologist how to approach the analysis of data, including the clarification of the (at any rate, to him) elementary mathematical points at issue, and for his insistence that genetical experiments should be designed with the same care as agronomical experiments, including the calculation of the laboratory resources that would be required. In the case of mouse experiments this was done in terms of mouse-cage-months, and Fisher often based his calculations on optimistic figures for speed and prolificacy of breeding. One soon learned that outright argument about this would serve only to irritate him, but a continuing attitude of concern would lead him to accept a programme more realistic in its expectations, particularly as the numbers of mice failed to mount in the expected way. One learned, also, to look after snails, grouse locusts and dogs as well as mice, and even for one brief period to look after some marsupials which he imported from Australia on the grounds that marsupial genetics had been sadly neglected.

Life with Fisher was indeed a neverending education. His kindness and patient helpfulness, especially to young people, was something that those of us who benefited from it will never forget. We also saw, however, how coldly and continuingly hostile he could be to those whom he suspected of being hostile to his views or obstinately misguided in their own. The mid-1930s saw too not only his last polemical exchange with Karl Pearson but the sad controversy with W. S. Gossett ("Student") with its revelation of a contentiousness so stubborn that it did not even spare an old friend. This contentiousness no doubt sprung from the treatment he had himself received (though not from Gossett) in his earlier struggling years, and it was no doubt also to these early years that we should trace Fisher's deep-seated distrust of accepted authority to whose nature he refers specifically in the introduction to the Design of Experiments.

Our personal recollections of this outstanding, and in some ways paradoxical, man can now be filled out and extended by the biography which his daughter, Mrs Joan Fisher Box, has written. It is a lengthy book, but for me at least it made compulsive reading. It supplies us with a full account of his ancestry and early life; and with it we can enter into the life of the Fisher family, its excitements, its happinesses and its sadnesses in a way which is possible only when looking through the eyes of one of the family itself. One can share Mrs Box's nostalgia in looking back at her childhood, as in the brief but touching account of Christmas in the Fisher household, including the story of how on one occasion "the existence of Father Christmas was challenged and one little boy stayed awake and saw for himself the figure who entered and filled the socks; he wore an unfamiliar long gown of

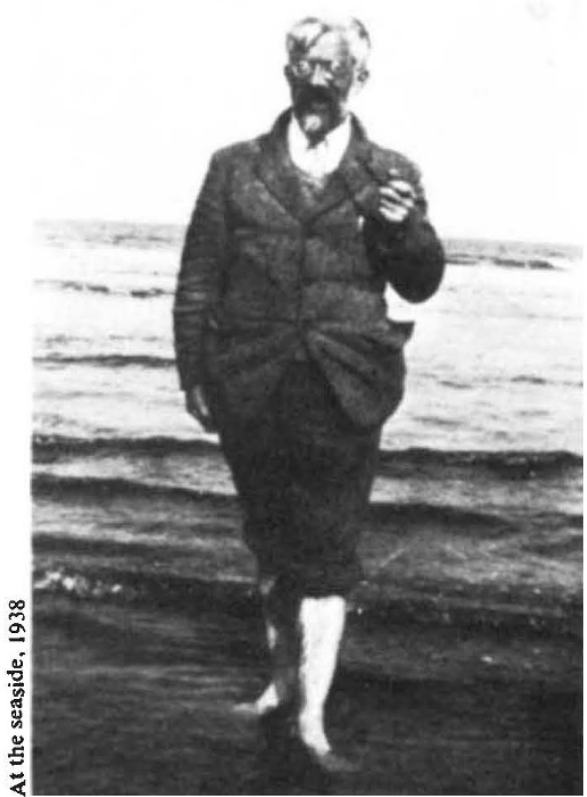




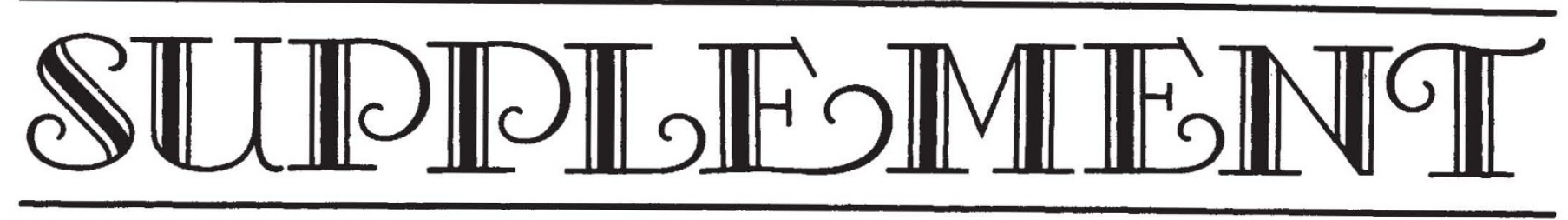

\section{Sorry, for copyright reasons some images on this page may not be available online}

scarlet silk, whose pink facings might have revealed to a more sophisticated watcher that Father Christmas was a doctor of science from Cambridge University; a mask with curling silver beard hid his features". This is true Fisher and a worthy addition to our store of Fisheriana. Nor does Mrs Box burke the sad story of the break-up of Fisher's marriage. She paints her father's picture in a way that would have met with Cromwell's approval"warts and all": blemishes as well as greatness.

It would, however, be wrong to leave any impression that the book is wholly, or even mainly, devoted to Fisher's family life and personal matters. On the contrary Mrs Box presents a full account of his scientific life, his scientific interests and scientific achievements, with which the more personal things are interwoven, as indeed must have been virtually inevitable in writing about Fisher. The early years, before 1919 , not only bring in reference to the paper he gave while still an undergraduate in 1911, in which his interests in biometry and genetics are foreshadowed, but also cover his two early major works on the exact distribution of the correlation coefficient and the correlations between relatives on the supposition of Mendelian inheritance-the latter now a genetical classic.

He went to Rothamsted in 1919 , initially for such time as a grant of $£ 200$ would cover, but stayed until 1933 . During these fourteen years he recast the whole theoretical basis of statistics and developed the modern methods of designing and analysing experiments, while at the same time he was generating his theory of the evolution of dominance and writing his seminal book The Genetical Theory of Natural Selection-and this genetical work was all carried out in his spare time.

When he succeeded Karl Pearson at the Galton Laboratory in 1933, he was able further to develop his genetical interests by undertaking genetical experiments on a sizeable scale and by founding the serological unit. But a wealth of statistical work continued, including the sharp defence of his basic approach against those who chose to criticise it. Much the same balance of interests continued in Cambridge where he succeeded R. C. Punnett as Professor of Genetics in 1943. The Cambridge days saw the publication of the Theory of Inbreeding, arising from some of his mouse experiments, and also Statistical Methods and Scienfic Inference in which he discusses at length the problems and logic of inductive inference. They also saw the flowering of the serological unit and the recognition by many honours from universities and academical bodies in a number of countries, as well as by the knighthood conferred on him in 1952. He travelled widely, especially in the USA and India where his ideas had a great influence, and after retirement in 1958 his Australian friends persuaded him to make his base in Adelaide where he died in z. 1962 .

Each period of his life can be seen as marked by its distinctive scientific achievement, springing from the pro-

blems which his various appointments

posed and the opportunities which they offered. It is a fascinating story which

¿ Mrs Box has to tell, and she tells it well. Her presentation and assessment of his work is comprehensive, balanced and informative, and she points to limitations where she sees them, as for example in Fisher's much smaller interest in the direct study of the hereditary materials than in the numerical relations to be found in breeding experiments.

This is indeed a fascinating book. To those who knew and worked with him it will bring the special pleasure of recalling a past association that was both memorable and eventful. To a wider audience it offers an account, at once informative and human, of a great scientist who gave us statistics as we now know it, while at the same time establishing himself among the great leaders of genetics especially in the study of natural selection and its impact on populations and their properties.

Kenneth Mather is Honorary Professor of Genetics at the University of Birmingham, UK. 